\title{
Pengaruh Ekonomi Makro dan Kinerja Manajemen Terhadap Return On Assets Perbankan Syariah
}

\author{
Ratih Hastasari \\ Universitas Bina Sarana Informatika \\ Email: ratih.rhs@bsi.ac.id
}
Cara Sitasi: Hastasari, R. (2019). Pengaruh Ekonomi Makro dan Kinerja Manajemen Terhadap Return On Assets Perbankan Syariah. Widya Cipta, 3(1), 115-122.

\begin{abstract}
Profitability is used as one measure to find out whether the bank has run its function as well. Based on these things, this research was conducted to test whether the macroeconomic factors such as Gross Domestic Bruto (GDP), inflation and the real exchange rate (RER), and from the side of the bank management performance such as Non Performing Finance (NPF) and The Ratio of Operational Expense to Operational Revenue (BOPO) have influence towards Return On assets (ROA) of Islamic Banking. The Data used in this research was obtained from the financial statements of Otoritas Jasa Keuangan online publication (2011-2017). The sample used is purposive sampling, these sample is 11 public bank of Sharia and 23 of Sharia business units. Data analysis technique that is used is multiple linear regression analysis and the first test performed classical assumptions to ensure the data has been BLUE. From the result of classical assumptions test is not found the variables that deviate from the classical assumptions test, this indicates that the data are qualified using regression analysis models. The results showed that the GDP influence positively and significantly toward ROA, inflation and real exchange rates (RER) do not influence significantly toward ROA, BOPO influences negatively and significantly toward ROA, and NPF influence significantly on ROA but having different direction with the hypothesis that has been proposed.
\end{abstract}

Keywords: ROA, PDB, Inflation, RER, BOPO, NPF

\section{PENDAHULUAN}

Seperti pada umumnya perusahaan bisnis, yang diharapkan dari bisnisnya adalah penghasilan dan laba. Penghasilan bank penting peranannya bagi setiap kelompok dalam perekonomian, yaitu pemegang saham, deposan, nasabah peminjam dan bagi masyarakat umum. Pemegang saham berkepentingan atas laba, karena laba merupakan hasil dari modal yang mereka tanamkan. Bagi deposan dan penabung, laba bermanfaat karena membuat bank menjadi lebih kuat, aman dan efisien melalui peningkatan cadangan dan perbaikan kualitas layanan. Peminjam memiliki kepentingan tidak langsung terhadap laba bank yang memadai, karena kesanggupan bank memberikan pinjaman/pembiayaan, tergantung pada besar dan struktur modal bank.

Laba bank merupakan sumber utama tambahan modal sendiri bank yang bersangkutan. Masyarakat umum yang tidak menggunakan pelayanan bank, juga memperoleh manfaat tidak langsung atas laba perbankan, karena sistem perbankan yang kuat akan memberikan keamanan deposit dan ketersedian kredit/pembiayaan bagi perekonomian (Darmawi, 2012).
Perbankan syariah di Indonesia baru muncul di tahun 1990-an sehingga dapat dikatakan bahwa keberadaannya sangat terlambat, mengingat hampir 90 persen penduduk Indonesia adalah muslim. Dimulai dengan pelopor pertama bank syariah, Bank Muamalat Indonesia di tahun 1992, yang kemudian terus berkembang sejak kemunculan UU Perbankan tahun 1998 tentang bank umum syariah dan izin bank konvensial untuk mendirikan unit usaha syariah, maka semenjak itu bermunculan banyak perbankan syariah lainnya (Yunitarini, 1997).

Profitabilitas merupakan kemampuan suatu perusahaan untuk menghasilkan keuntungan, yang menunjukkan kemampuan perusahaan untuk menghasilkan laba selama periode waktu tertentu. Profitabilitas suatu perusahaan salah satunya dapat diukur dengan kesuksesan perusahaan dan kemampuan perusahaan menggunakan aktivanya secara produktif (Machmud, 2010).

Dalam hal ini maka perolehan Laba terhadap total aktiva (ROA) akan dijadikan acuan sebagai alat ukur untuk melihat tingkat profitabilitas dalam kegiatan Perbankan syariah di Indonesia.

Semakin besar ROA suatu bank menunjukkan kinerja perusahaan semakin baik, karena return yang semakin 
besar menunjukkan semakin besar pula tingkat keuntungan yang dicapai bank tersebut dan semakin baik pula posisi bank tersebut dari sisi penggunaan aset.

ROA $=\frac{\text { Laba Sebelum Pajak }}{\text { Total Aktiva }} \times 100 \%$

Return on Asset digunakan untuk mengukur keberhasilan manajemen dalam menghasilkan keuntungan. Semakin kecil rasio persentase mengindikasikan kurangnya kemampuan manajemen bank dalam hal mengelola aktiva untuk meningkatkan pendapatan dan atau menekan biaya (Bank Indonesia, 2011).

Tabel 1. Kriteria Penilaian Peringkat

\begin{tabular}{cc}
\hline Peringkat & ROA \\
\hline 1 & $>1,5 \%$ \\
2 & $1.25 \%<\mathrm{ROA} \leq 1,5 \%$ \\
3 & $0,5 \%<\mathrm{ROA} \leq 1.25 \%$ \\
4 & $0 \%<\mathrm{ROA} \leq 0,5 \%$ \\
5 & $\mathrm{ROA} \leq 0 \%$ \\
\hline
\end{tabular}

Sumber : Surat Edaran Bank Indonesia, 2011

Menurut surat edaran Bank Indonesia tahun 2011, ROA yang baik nilainya lebih dari $1,25 \%$ (Margaretha \& Zai, 2013). Bank Indonesia mensyaratkan tingkat ROA yang baik yaitu diatas $1.25 \%$.

Pertumbuhan ROA perbankan syariah secara nasional Indonesia dapat dilihat pada tabel 1.2 berikut. Tahun 2011 sampai dengan 2013 ROA perbankan syariah berada pada kategori peringkat 1 yang berarti Bank memiliki tingkat Laba yang sangat baik, namun terjadi penurunan yang signifikan pada 2014 sampai dengan 2017 dimana laba bank hanya masuk pada ketegori kurang dan cukup baik saja. Penurunan tersebut memerlukan analisa mengapa hal tersebut dapat terjadi. Perlahan kenaikan terjadi lagi di tahun 2018 pada tingkat ROA $1,26 \%$ dan diharapkan akan terus membaik pada tahun-tahun berikutnya.

Tabel 2 ROA Gabungan BUS dan UUS

\begin{tabular}{cc}
\hline Tahun & ROA \\
\hline 2011 & $1.80 \%$ \\
2012 & $2.14 \%$ \\
2013 & $2.00 \%$ \\
2014 & $0.41 \%$ \\
2015 & $0.49 \%$ \\
2016 & $0.63 \%$ \\
2017 & $0.63 \%$ \\
2018 & $1.26 \%$ \\
\hline
\end{tabular}

Sumber : Data diolah dari statistik OJK, www.ojk.go.id
Naik turunnya ROA dapat dipengaruhi oleh faktor internal dan eksternal. Faktor-faktor internal yang dapat di kendalikan oleh bank antara lain adalah : bauran bisnis, penciptaan laba, pengeluaran biaya, kualitas pembiayaan dan likuiditas, dan selain dari analisa secara kuantitatif perlu juga dilihat dari sisi kinerja manajemen. Faktor eksternal yang dapat mempengaruhi profit bank antara lain gejolak perekonomian seperti naik turunnya inflasi, kurs, jumlah uang beredar, dan PDB, selain juga karena perubahan peraturan dan kebijakan pemerintah, berubahnya selera konsumen, perubahan teknologi dan sebagainya.

Faktor makro lainnya yang dapat mempengaruhi profitabilitas bank syariah, misalnya faktor politik dan ekonomi, faktor ekonomi seperti pertumbuhan ekonomi, tingkat inflasi, fluktuasi nilai tukar, suku bunga, money supply, kapasitas produksi nasional, tingkat konsumsi nasional, pengangguran, dan ekspor-impor, dapat berimbas pada kinerja perbankan baik langsung maupun tidak langsung. Sementara itu dari sisi faktor politik, seperti peperangan, intervensi Bank Sentral, peralihan kekuasaan, dan stabilitas nasional juga akan berpengaruh terhadap profitabilitas perbankan.

Faktor-faktor makro yang akan dipilih untuk dianalisa adalah Gross Domestic Bruto (GDP), inflasi, dan nilai tukar riil (NTR).

Faktor lain yang juga berpengaruh terhadap profit bank adalah dari sisi kinerja manajemen bank itu sendiri yang dapat diukur melalui Capital Adequancy Ratio (CAR), Non Performing Financing (NPF), Rasio Pembiayaan terhadap Dana Pihak Ketiga atau biasa di sebut Financing to Deposits Ratio (FDR), Rasio Biaya Operasional terhadap Pendapatan Operasional (BOPO), Return On Equity (ROE), pertumbuhan jumlah institusi, dan pertumbuhan jumlah nasabah.

Faktor-faktor Kinerja Manajemen yang akan dipilih untuk di analisa antara lain: Rasio Biaya Operasional (BOPO), dan Non Performing Financing (NPF)

\section{BOPO}

Rasio biaya operasional (BOPO) digunakan untuk mengukur tingkat efisiensi dan kemampuan bank dalam melakukan kegiatan operasinya. Mengingat kegiatan utama bank adalah bertindak sebagai perantara, yaitu menghimpun dan menyalurkan dana, maka biaya pendapatan operasionalnya dalam bank Syariah untuk perhitungan BOPO, dalam hal pendapatan operasional didapat dari tingkat bagi hasil dan biaya sewa. Tingkat efisiensi kinerja bank disebut baik jika rasio BOPO $\leq 96 \%$ (Margaretha \& Zai, 2013). Persamaan BOPO adalah sebagai berikut:

BOPO $=\frac{\text { Biaya }(\text { Beban }) \text { Operasional }}{\text { Pendapatan Operasional }} \times 100 \%$ 
Rasio BOPO yang melebihi 96\%, mengindikasikan bahwa Bank dinyatakan tidak sehat, karena bank dianggap tidak efisien dalam menjalankan aktivitas operasionalnya (Margaretha \& Zai, 2013).

\section{NPF}

Tingkat kelangsungan usaha bank dapat dilihat dari aktiva produktif yang dimilikinya, oleh karena itu manajemen bank harus senantiasa memantau dan menganalisa kualitas aktiva produktif yang dimiliki. Penilaian kualitas aktiva produktif dilakukan dengan menentukan tingkat kolektibilitasnya. Kolektibilitas merupakan tingkat kelancaran pembayaran kewajiban nasabah yang berdasarkan jumlah hari tunggakan (Suhada, 2009).

$N P F=\frac{\text { Pembiayaan }}{\text { Total Pembiayaan }} \times 100 \%$

Kriteria penilaian peringkat NPF menurut Surat Edaran BI tahun 2011, yaitu :

Tabel 3 Peringkat NPF

\begin{tabular}{cc}
\hline Peringkat & NPF \\
\hline 1 & $<2 \%$ \\
2 & $2 \% \leq \mathrm{NPF} \leq 5 \%$ \\
3 & $5 \% \leq \mathrm{NPF} \leq 8 \%$ \\
4 & $8 \% \leq \mathrm{NPF} \leq 12 \%$ \\
5 & $\mathrm{NPF} \geq 12 \%$ \\
\hline
\end{tabular}

Sumber : Surat Edaran BI tahun 2011

Pembiayaan yang diberikan kepada nasabah tidak akan lepas dari risiko terjadinya NPF (pembiayaan bermasalah) yang pada akhirnya dapat mempengaruhi kinerja perbankan syariah, karena semakin tinggi persentase NPF maka semakin tidak sehat bank tersebut.

Dalam penelitian ini variabel-variabel yang diteliti dibatasi dengan pilihan variabel yang dianggap paling dapat mempengaruhi profitabilitas perbankan syariah antara lain, PDB, inflasi, nilai tukar, NPF dan BOPO.. Maka variabel yang dipilih bertujuan untuk melihat variabel apa yang akan sangat berpengaruh terhadap tingkat profitabilitas (ROA) bank syariah,

\section{METODOLOGI PENELITIAN Jenis dan Sumber Data}

Data - data yang digunakan dalam penelitian ini adalah data time series tahun 2011 s/d 2017. Jenis data yang digunakan dalam penelitian ini adalah jenis data sekunder, yaitu data penelitian yang diperoleh secara tidak langsung atau melalui media perantara dalam hal ini adalah data publik pada Bank Indonesia dan Otoritas Jasa Keuangan, yaitu berupa laporan bulanan dan tahunan yang dipublikasikan secara online melalui website resmi. Selain itu data sekunder lainnya yang digunakan berasal dari Jurnal, Skripsi dan Tesis.

\section{Populasi dan Sampel}

Populasi dalam penelitian ini adalah perbankan syariah Indonesia yang terdaftar di Bank Indonesia pada tahun 2011 - 2017. Jumlah bank syariah yang ada di Indonesia adalah 188 bank, yang terdiri dari 11 bank umum syariah, 23 unit usaha syariah, dan 154 BPR syariah.

Sampel penelitian diambil secara purposive sampling yaitu metode dimana pemilihan sampel pada karakteristik populasi yang sudah diketahui sebelumnya dengan kriteria sebagai berikut :

1. Perbankan syariah yang terdiri dari Bank Umum Syariah (BUS) dan Unit Usaha Syariah (UUS).

2. Bank Umum Syariah dan Unit Usaha Syariah tersebut membuat laporan keuangan pada periode 2005 - 2011 dan telah dipublikasikan di Bank Indonesia.

3. Data yang dibutuhkan untuk penelitian adalah data kuartal yang tersedia pada website Bank Indonesia selama periode tahun $2005-2011$.

Berdasarkan kriteria tersebut sampel yang dapat digunakan adalah 11 Bank Umum Syariah dan 23 Unit Usaha Syariah.

\section{Teknik Pengumpulan Data}

Data sekunder dikumpulkan melalui penelitian arsip, dan studi kepustakaan, metode yang dilakukan dalam penelitian ini adalah:

1. Observasi tidak langsung, dengan membuka dan mendownload laporan online dari objek penelitian sehingga diperoleh laporan keuangan, gambaran umum bank serta perkembangannya, dan laporan pertumbuhan ekonomi seperti data - data PDB, inflasi dan nilai tukar. Adapun situs yang digunakan berasal dari website resmi Bank Indonesia (BI), Otoritas Jasa Keuangan (OJK), dan Badan Pusat Statistik (BPS).

2. Penelitian kepustakaan, dengan cara mempelajari dan memahami buku-buku yang mempunyai hubungan dengan bank syariah, profitabilitas, jurnal keuangan perbankan, media masa dan hasil penelitian yang diperoleh dari berbagai sumber, serta berbagai pembahasan mengenai ekonomi makro dan pertumbuhan ekonomi nasional.

\section{Instrumen Penelitian}

Variabel terikat dalam penelitian ini adalah Return On Assets (ROA), yaitu rasio antara laba sebelum pajak dengan total aktiva. ROA digunakan untuk mengukur kemampuan manajemen bank dalam memperoleh keuntungan (laba) secara relatif 
dibandingkan dengan nilai total asetnya (Susilo, et.al, 2000).

Variabel bebas dalam penelitian ini antara lain adalah Produk Domestik Bruto (PDB), Inflasi, Nilai Tukar Riil (RER), Biaya operasional terhadap Pendapatan Operasional (BOPO), dan Non Performing Financing (NPF).

\section{Kerangka Berpikir dan Hipotesis}

Penelitian ini menggunakan 5 variabel bebas yang diteliti, yaitu PDB, Inflasi, Nilai tukar riil, BOPO dan $\mathrm{NPF}$, dan variable terikat ROA. Kerangka penelitian untuk mempermudah pemahaman mengenai hubungan antar variable yaitu sebagai berikut :

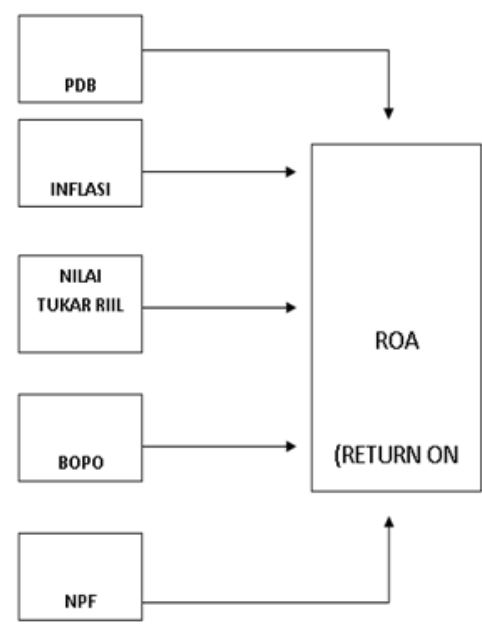

Gambar 1 Kerangka Pemikiran

Hipotesis yang digunakan dalam penelitian ini adalah sebagai berikut :

H1: diduga bahwa PDB akan berpengaruh positif terhadap ROA

$\mathrm{H} 2$ : diduga bahwa Inflasi akan berpengaruh negatif terhadap ROA

H3: diduga bahwa Nilai Tukar Rupiah akan berpengaruh negatif terhadap ROA

H4: diduga bahwa BOPO akan berpengaruh negatif terhadap ROA

H5: diduga bahwa NPF akan berpengaruh negatif terhadap ROA

\section{HASIL DAN PEMBAHASAN}

Analisis data yang dilakukan adalah analisis kuantitatif dengan data kuantitatif yaitu data berupa angka dalam arti sebenarnya (Santoso, 2012) dan perhitungannya menggunakan metode statistik yang dibantu dengan program SPSS 18. Analisa data yang digunakan dalam penelitian ini yaitu pengujian asumsi klasik, analisis regresi berganda, dan uji hipotesis.
Dalam penelitian ini data yang digunakan adalah data triwulan gabungan 11 BUS dan 23 UUS yaitu, ROA, NPF, BOPO yang diperoleh melalui data statistik online OJK tahun 2011-2018, serta data-data triwulan ekonomi makro yaitu PDB, inflasi dan nilai tukar riil (NTR) rupiah yang diperoleh melalui data statistik online BPS tahun 2011-2018.

Sebelum melakukan regresi terhadap data, maka terlebih dahulu dilakukan uji asumsi klasik, guna melihat apakah data sudah layak digunakan untuk melakukan estimasi, yang artinya model regresi dapat menghasilkan estimator yang BLUE (Best Linear Unbiased Estimator) (Ghozali, 2011).

Uji asumsi klasik yang digunakan, yaitu :

a. Uji Normalitas dengan Kolmogorov-Smirov Untuk mengujii normalitas data pada penelitian ini menggunakan uji statistik Kolmogorov-Smirnov. Model regresi yang baik adalah model yang memiliki distribusi data normal atau mendekati normal (Ghozali, 2011).

Tabel 4. Uji Normalitas

One-Sample Kolmogorov-Smirnov Test

Unstandar

dized

Residual

\begin{tabular}{llr}
\hline $\mathrm{N}$ & 28 \\
\hline Normal & Mean & .0000000 \\
\cline { 2 - 3 } Parameters ${ }^{\mathrm{a}, \mathrm{b}}$ & Std. Deviation & .2309176 \\
& &
\end{tabular}

\begin{tabular}{llr}
\hline Most Extreme & Absolute & .130 \\
\cline { 2 - 3 } Differences & Positive & .080 \\
\cline { 2 - 3 } & Negative & -.130 \\
\hline
\end{tabular}

Kolmogorov-Smirnov Z .689

Asymp. Sig. (2-tailed) .730

a. Test distribution is Normal.

b. Calculated from data.

Dari hasil olah spss diatas besarnya nilai Kolmogorov-Smirnov adalah 0.689 dan signifikansi pada 0.730 , hal ini berarti data residual terdistribusi normal $(0.730>0.05)$. Hasilnya dapat disimpulkan bahwa data terdistribusi normal.

\section{b. Uji Multikolinieritas}

Uji Multikolinieritas bertujuan untuk menguji apakah model regresi ditemukan adanya korelasi antar variabel bebas (independen). Model regresi yang baik adalah yang antar variabel bebasnya tidak terjadi korelasi (Ghozali, 2011). 
Tabel 5. Uji Multikolinieritas - Koefisien Korelasi

\begin{tabular}{lrrrrr}
\hline \multicolumn{1}{c}{$\begin{array}{c}\text { Model } \\
\text { correlations }\end{array}$} & NPF & INFLASI & NTR & BOPO & PDB \\
\hline NPF & 1 & & & & \\
INFLASI & 0.31 & 1 & & & \\
NTR & 0.08 & -0.04 & 1 & & \\
BOPO & 0.09 & -0.136 & 0.333 & 1 & \\
PDB & 0.24 & 0.584 & -0.39 & -0.58 & 1 \\
\hline
\end{tabular}

Sumber : Data diolah melalui hasil spss

Melihat hasil besaran antar variabel independen tampak bahwa korelasi ini masih berada di bawah 95\% maka dapat dikatakan tidak terjadi multikolinieritas yang serius.

\section{c. Uji Heteroskedastisitas dengan uji Glejser}

Uji Heteroskedastisitas bertujuan untuk menguji apakah dalam model regresi tidak terjadi kesamaan variance dari residual satu pengamatan ke pengamatan lainnya. Model regresi yang baik adalah yang homoskedastisitas atau yang tidak heteroskedastisitas (Ghozali, 2011).

\begin{tabular}{llccc}
\multicolumn{5}{c}{ Tabel 6. Uji Glejser } \\
\hline Model & $\begin{array}{c}\text { Standardized } \\
\text { Coefficients } \\
\text { Beta }\end{array}$ & $\mathrm{t}$ & Sig. \\
\hline \multicolumn{1}{c}{ (Constant } & & 2.005 & 0.06 \\
& PDB & -0.417 & -1.28 & 0.21 \\
1 & INFLASI & -0.166 & -0.66 & 0.52 \\
NTR & 0.074 & 0.344 & 0.73 \\
& NOPO & -0.208 & -0.83 & 0.42 \\
& BOPF & -0.089 & -0.43 & 0.67 \\
\hline
\end{tabular}

Sumber : data diolah melalui hasil spss

Dari hasil pengolahan data terlihat probabilitas signifikansi pada variabel bebas diatas semua berada diatas tingkat kepercayaan 5\%. Sehingga dapat disimpulkan bahwa model regresi tidak mempunyai masalah heteroskedastisitas.

\section{d. Uji Autokorelasi}

Uji autokorelasi bertujuan untuk menguji apakah dalam model regresi linier terdapat korelasi antara kesalahan pengganggu pada periode $t$ dengan kesalahan pengganggu pada periode $\mathrm{t}-1$ (sebelumnya) (Ghozali, 2011). Dalam penelitian ini untuk menguji terdapat atau tidaknya masalah autokorelasi maka dilakukan dengan uji Durbin-Watson (DW test) dan dengan Run test.

Ketika dilakukan uji autokorelasi menggunakan Durbin-Watson, hasil yang didapat adalah nilai berada pada posisi "no decision' yang artinya tidak dapat diputuskan apakah data mengandung masalah autokorelasi atau tidak, untuk itu diputuskan untuk menggunakan uji statistik "Run Test"
Tabel 7. Run Test

\begin{tabular}{lr}
\hline & Unstandardized Residual \\
\hline Test Value $^{\mathrm{a}}$ & 0.04325 \\
Cases $<$ Test Value & 14 \\
Cases $>=$ Test Value & 14 \\
Total Cases & 28 \\
Number of Runs & 15 \\
Z & 0 \\
Asymp. Sig. (2- & 1 \\
tailed) & 1 \\
\hline
\end{tabular}

Sumber : data diolah melalui hasil spss

Hasil olah SPSS dengan Run Test menunjukkan bahwa nilai test adalah 0.04325 dengan probabilitas 1.000. Sebagai pedoman jika hasil olah SPSS Run test pada Asymp Sig. > 5\% maka data tidak mengandung autokorelasi dan sebaliknya (Ghozali, 2011). Dengan probabilitas/ Asymp Sig. bernilai 1.000 maka 1.000 > 0.05 , sehingga dapat disimpulkan bahwa residual random atau tidak terjadi autokorelasi antar nilai residual.

Setelah melalui semua uji asumsi klasik maka didapat hasil bahwa data sudah layak digunakan untuk melakukan estimasi, karena sudah memenuhi asumsi klasik, yang artinya model regresi dapat menghasilkan estimator yang BLUE (Best Linear Unbiased Estimator).

Hasil pengujian terhadap model regresi berganda terhadap faktor-faktor yang mempengaruhi ROA pada perbankan Syariah Indonesia, ditunjukkan pada tabel berikut :

Tabel 8. Hasil Estimasi Regresi Berganda Coefficients $^{\mathrm{a}}$

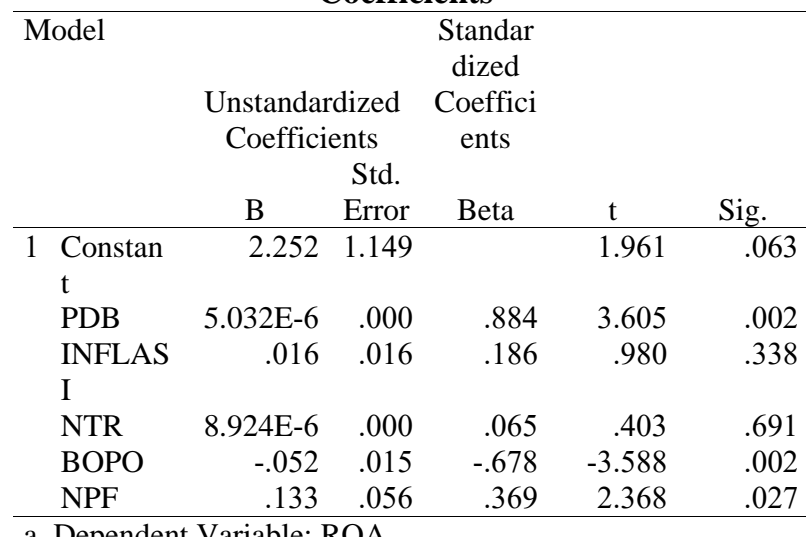

a. Dependent Variable: ROA

Model persamaan regresi linier berganda yang di dapat dari hasil estimasi dengan data yang sudah memenuhi uji asumsi klasik adalah sbb :

$\mathrm{ROA}=\mathrm{b}_{0}+\mathrm{b}_{1} \mathrm{PDB}+\mathrm{b}_{2} \mathrm{INFLASI}+\mathrm{b}_{3} \mathrm{NTR}+\mathrm{b}_{4} \mathrm{BOPO}$ $+\mathrm{b}_{5} \mathrm{NPF}$

Dengan memasukkan nilai-nilai estimasi regresi, di dapat persamaan sebagai berikut: 
$\mathrm{ROA}=2.252+5.032(10)^{-6} \mathrm{PDB}+0.016 \mathrm{INFLASI}+$ $8.924(10)^{-6} \mathrm{NTR}-0.052 \mathrm{BOPO}+0.133 \mathrm{NPF}$

Berdasarkan persamaan regresi linier berganda diatas diperoleh koefisien regresi PDB sebesar (+) 0.000005032 , koefisien tersebut mengindikasikan adanya hubungan positif antara variabel PDB dengan ROA. Koefisien regresi inflasi sebesar (+) 0.016 mengindikasikan adanya hubungan positif antara inflasi dengan ROA. Koefisien regresi Nilai Tukar Riil (NTR) sebesar (+) 0.00000892 mengindikasikan adanya hubungan positif antara nilai tukar riil dengan ROA. Koefisien regresi BOPO sebesar (-) 0.052 mengindikasikan adanya hubungan negatif antara BOPO dengan ROA. Dan terakhir koefisien regresi NPF sebesar (+) 0.133 mengindikasikan adanya hubungan positif antara NPF dan ROA.

Penelitian ini menggunakan uji t, uji t dilakukan untuk menghitung koefisien regresi variabel bebas secara individu terhadap variabel terikat. Uji $t$ ini dilakukan dengan membandingkan nilai probabilitas sig.- $t$ dengan nilai signifikansi 0.05 . Jika nilai probabilitas sig.- $t$ lebih kecil dari 0.05 maka Ha diterima, sedangkan jika probabilitas sig.- $t$ lebih besar dari 0.05 maka Ha ditolak.

Tabel 9. Hasil Uji t

\begin{tabular}{lccr}
\hline Model & T & Sig. & Kesimpulan \\
\hline (Constant) & 1.961 & 0.063 & - \\
\hline PDB & 3.605 & 0.002 & Signifikan \\
\hline INFLASI & 0.98 & 0.338 & $\begin{array}{r}\text { tidak } \\
\text { signifikan }\end{array}$ \\
\hline NTR & 0.403 & 0.691 & signifikan \\
\hline BOPO & -3.59 & 0.002 & Signifikan \\
\hline NPF & 2.368 & 0.027 & Signifikan \\
\hline
\end{tabular}

Sumber: Data diolah dari output spss

Hasil uji t pada tabel 3.2 menunjukkan bahwa pada variabel Inflasi dan NTR nilainya jauh diatas 0.05 , artinya Ha ditolak artinya inflasi dan nilai tukar riil tidak berpengaruh secara signifikan terhdap ROA, sementara itu variabel PDB, BOPO dan NPF berpengaruh secara signifikan terhdap ROA.

Dari hasil uji t diatas dapat dilakukan pembahasan hipotesis yang diajukan sebagai berikut :

1. H1 : PDB berpengaruh positif terhadap ROA

Berdasarkan Uji t diperoleh nilai t hitung sebesar 3.605 dengan tingkat signifikansi 0.002. Karena tingkat signifikansi lebih besar dari 0.05 maka secara parsial variabel PDB berpengaruh secara signifikan terhadap ROA. Dengan demikian H1 diterima artinya terdapat pengaruh yang signifikan secara parsial terhadap ROA.

2. H2 : Inflasi berpengaruh negatif terhadap ROA Berdasarkan Uji t diperoleh nilai t hitung sebesar 0.980 dengan tingkat signifikansi 0.338 . Karena tingkat signifikansi lebih besar dari 0.05 maka secara parsial variabel inflasi tidak berpengaruh secara signifikan terhadap ROA. Dengan demikian H2 ditolak artinya tidak terdapat pengaruh yang signifikan secara parsial terhadap ROA.

3. H3 : Nilai Tukar Riil (NTR) berpengaruh negatif terhadap ROA

Berdasarkan Uji t diperoleh nilai t hitung sebesar 0.403 dengan tingkat signifikansi 0.691. Karena tingkat signifikansi lebih besar dari 0.05 maka secara parsial variabel nilai tukar riil tidak berpengaruh secara signifikan terhadap ROA. Dengan demikian $\mathbf{H 3}$ ditolak artinya tidak terdapat pengaruh yang signifikan secara parsial terhadap ROA.

4. H4 : BOPO berpengaruh negatif terhadap ROA

Berdasarkan Uji t diperoleh nilai t hitung sebesar3.588 dengan tingkat signifikansi 0.002 . Karena tingkat signifikansi jauh lebih kecil dari 0.05 maka secara parsial variabel nilai tukar riil berpengaruh secara signifikan terhadap ROA. Dengan demikian H4 diterima artinya terdapat pengaruh yang signifikan secara parsial terhadap ROA.

5. H5 : NPF berpengaruh negatif terhadap ROA

Berdasarkan Uji t diperoleh nilai t hitung sebesar 2.368 dengan tingkat signifikansi 0.027. Karena tingkat signifikansi lebih kecil dari 0.05 maka secara parsial variabel NPF berpengaruh secara signifikan terhadap ROA, namun berbeda arah secara hipotesa yang diajukan, yaitu positif yang artinya tidak sesuai dengan hipotesa, maka H5 ditolak.

Hasil uji analisa statistik yang di peroleh dari penelitian ini secara makro ekonomi yaitu pada variabel Pendapatan Domestik Bruto (PDB) secara signifikan mempengaruhi profitabilitas bank syariah yang di proksi dengan ROA. Menurut Umer Chapra (1998) pertumbuhan ekonomi yang di wakili dengan pertumbuhan PDB merupakan salah satu indikasi yang mempengaruhi keberhasilan pertumbuhan perbankan syariah di berbagai negara. Termasuk juga di Indonesia faktor peningkatan PDB mengakibatkan naiknya nilai investasi. Apabila yang diterapkan adalah konsep perekonomian islam maka menurut Karim (Karim, 2014) tingkat bunga tidak masuk dalam perhitungan investasi. Investasi dalam perekonomian islam adalah fungsi dari tingkat keuntungan yang diharapkan. Tingkat keuntungan yang diharapkan juga bergantung pada bagian relatif dari keuntungan (bagi hasil) yang dialokasikan antara investor dan mereka yang meyediakan dana-dananya (perbankan syariah) pada bentuk kerjasama atau pinjaman. Hasil penelitian ini sesuai dengan 
penelitian Samir Abderrazek (Srairi, 2009) dan tidak sesuai dengan penelitian Adi Stiawan (Stiawan, 2010) yang mengatakan bahwa PBD tidak mempengaruhi ROA.

Hasil uji analisa statistik yang diperoleh untuk inflasi dan nilai tukar tidak mempengaruhi secara signifikan terhadap ROA. Terdapat hubungan kausalitas antara inflasi dan nilai tukar, setiap kali terjadi nilai tukar yang terdepresiasi maka akan berdampak pada inflasi. Inflasi sesungguhnya mencerminkan kestabilan sebuah mata uang. Stabilitas tersebut tercermin dari stabilitas tingkat harga yang kemudian berpengaruh pada realisasi pencapaian tujuan pembangunan ekonomi suatu negara seperti pemenuhan kebutuhan dasar, pemerataan distribusi pendapatan dan kekayaan, perluasan kesempatan kerja dan stabilitas ekonomi.

Dalam rangka pemgendalian inflasi dan menjaga stabilnya mata uang, pemerintah dan otoritas moneter membuat kebijakan yang salah satunya dengan menaikkan suku bunga (Riset \& Moneter, 1999). Hampir semua sektor ekonomi konvensional terkait dengan sistem bunga, mulai dari sektor riil dan non riil. Sistem bunga mengakibatkan sektor non riil berkembang lebih cepat, hal ini di karenakan sektor non riil memberikan keuntungan lebih cepat dan besar jumlahnya. Karena Islam melarang bunga maka peran bank syariah untuk ikut serta dalam perekonomian yang menganut sistem bunga menjadi terbatas geraknya (Antonio, 2014). Sehingga pada akhirnya setiap perubahan pada inflasi dan nilai tukar tidak berpengaruh signifikan pada profitabilitas perbankan syariah. Hal ini sesuai dengan penelitian Adi Stiawan (Stiawan, 2010) yang menyebutkan bahwa inflasi tidak berpengaruh secara signifikan terhadap ROA, Namun tidak sesuai dengan penelitian Samir Abderrazek (2009) yang menyatakan inflasi berpengaruh pada ROA.

Secara kinerja manajemen, variabel bebas yang diproksi dengan BOPO menunjukkan bahwa efisiensi dalam sebuah kinerja operasional perbankan syariah memiliki pengaruh yang signifikan terhadap profitabilitas perbankan syariah. Secara parsial hasil regresi memberikan kesimpulan bahwa semakin efisien kinerja operasional bank syariah maka keuntungan yang diperoleh akan semakin besar. Bagi pihak manajemen bank hal ini menunjukkan pentingnya memperhatikan pengendalian biaya-biaya operasional sehingga dapat menghasilkan rasio BOPO dibawah $96 \%$ yang sesuai dengan ketentuan BI mengenai kriteria bank yang sehat.

Manajemen didalam bank syariah didorong oleh motif mendapatkan keuntungan, maka kinerja manajemen haruslah diselenggarakan dengan efisien. Hasil penelitian in konsisten dengan hasil penelitian Adi Stiawan (2010), dan Samir Abderrazek (2009).
Hasil regresi parsial pada variabel bebas NPF memberikan hasil signifikan berpengaruh pada ROA, namun berbeda arah, maka hal ini menunjukan kemampuan manajemen melakukan penanganan pembiayaan bermasalah. Pada pembiayaan bermasalah dalam kategori diragukan atau macet, bank syariah melakukan penanganan dengan beberapa cara, diantaranya, reschedulling, yaitu menjadwal kembali jangka waktu angsuran, reconditioning, yaitu memperkecil margin keuntungan atau bagi hasil usaha, dan yang berikutnya adalah dengan cara melakukan pengalihan atau pembiayaan ulang dalam bentuk al-Qardhul Hasan, yaitu mengangsur pokok saja (tanpa margin). Apabila ketiga cara tersebut tidak dihiraukan nasabah, maka cara terakhir yang terpaksa dilakukan oleh pihak bank adalah menyita dan menjual jaminan dan menyita barang yang senilai dengan nilai pembiayaan. Kedua prosedur ini dapat dilakukan apabila sudah ada perjanjian tertulis dan umumnya pada saat akad maka kedua hal tersebut tertulis dalam akad tersebut (Muhammad, 2002). Dengan begitu permasalahan pada tinggi rendahnya NPF tidak akan berpengaruh signifikan pada ROA, karena bank memiliki cara-cara tersendiri untuk mengatasi pembiayaan bermasalah hingga tidak mempengaruhi ROA.

\section{KESIMPULAN}

Setelah melakukan analisis maka kesimpulan yang dapat diambil adalah sebagai berikut:

1. Secara parsial variabel ekonomi makro sebagai variabel bebas yang diproksi dengan PDB memberikan hasil yang berpengaruh signifikan positif terhadap ROA perbankan syariah. Naiknya PDB akan mendorong investasi, sehingga diharapkan pula akan menambah tingkat laba perbankan syariah.

2. Inflasi dan nilai tukar memberikan hasil yang tidak berpengaruh signifikan terhadap ROA perbankan syariah. Dalam hal ini menurut penulis disebabkan oleh karena inflasi dan nilai tukar memiliki hubungan kausalitas, yang secara moneter diatasi dengan memainkan suku bunga yang lebih dominan berpengaruh pada sektor non riil, sementara karena bank syariah adalah sebuah lembaga keuangan yang tidak menganut sistem bunga, inflasi dan nilai tukar riil tersebut pada akhirnya tidak mempengaruhi pada ROA perbankan syariah secara umum.

3. Secara parsial variabel BOPO mempunyai hubungan yang secara negatif signifikan mempengaruhi ROA perbankan syariah. Hal ini membuktikan bahwa semakin efisien kinerja operasional perbankan syariah maka keuntungan yang diperoleh akan semakin besar.

4. Secara parsial variabel NPF memberikan hasil berpengaruh secara signifikan terhadap ROA 
perbankan syariah, namun berbeda arah dengan hipotesa yang diajukan. Hal ini disebabkan oleh karena bank memiliki cara-cara tersendiri untuk mengatasi pembiayaan bermasalah hingga tidak mempengaruhi ROA perbankan syariah.

Berdasarkan penelitian diatas, maka beberapa saran berikut dapat dijadikan bahan pertimbangan dalam membuat keputusan bagi para pelaku di bidang perbankan syariah dalam hal peningkatan ROA perbankan syariah di Indonesia. Adapun saran-saran tersebut antara lain:

1. Perbankan syariah perlu memberi perhatian khusus dalam menjaga tingkat efisiensi kinerja operasionalnya, dengan melakukan pengendalian pada biaya-biaya operasional sehingga di capai suatu kinerja yang sangat efisien, karena berdasarkan penelitian semakin efisien maka keuntungan semakin tinggi.

2. Perbankan syariah harus lebih hati-hati dalam melakukan penyaluran dana/ pembiayaan yang akan menimbulnya pembiayaan bermasalah, dan senantiasa lebih fokus dalam menangani pembiayaan yang sudah terlanjur bermasalah, tentunya dengan cara-cara yang sesuai syariah.

3. Dalam menjalankan operasionalnya perbankan syariah tetap mengacu pada kondisi makro ekonomi lainnya sebagai pertimbangan untuk mencari cara-cara yang lebih baik dan kreatif yang tentunya sesuai syariah dalam hal penghimpunan maupun penyaluran dana, dan usaha pelayanan jasa lainnya yang tujuannya untuk meningkatkan laba.

\section{REFERENSI}

Antonio, M. S. (2014). Analisis pengaruh variabel ekonomi makro terhadap nilai. Bisnis Dan Manajemen.

Darmawi, H. (2012). Manajemen Perbankan. Jakarta: Bumi Aksara.

Ghozali, I. (2011). Aplikasi Analisis Multivariat dengan program SPSS.

Indonesia, B. (2011). Lampiran 6.1 82.

Karim, A. A. (2014). ekonomi mikro islami. Rajawali Pers.

Machmud, A. (2010). Bank Syariah: Teori, Kebijakan dan Studi Empirik di Indonesia.

Margaretha, F., \& Zai, M. P. (2013). Kinerja Keuangan Perbankan Indonesia dan FaktorFaktor yang Mempengaruhi. Jurnal Bisnis Dan Akuntansi.

Muhammad. (2002). Manajemen bank syari'ah. UPP $A M P Y K P N$.

Riset, D., \& Moneter, K. (1999). Mekanisme Pengendalian Moneter dengan Inflasi sebagai Sasaran Tunggal. Bank Indonesia, 68-122.

Santoso, S. (2012). Buku Latihan SPSS Statistik Parametik. Analisis SPSS Pada Statistik Parametik.

Srairi, S. A. (2009). Factors Influencing the Profitability of Conventional and Islamic Commercial Banks in GCC Countries. Review of Islamic Economics.

Stiawan, A. (2010). Analisis Pengaruh Faktor Makroekonomi, Pangsa Pasar Dan Karakteristik Bank Terhadap Profitabilitas Bank Syariah. Manajemen Keuangan, 1-100.

Yunitarini, S. (1997). Prospek dan Kendala Bank Syariah di Era Global.

\section{PROFIL PENULIS}

Nama Ratih Hastasari, saat ini aktif mengajar di Universitas Bina Sarana Informatika dengan kosentrasi Statistika, Perbankan, dan Enterpreneur. 